〔J. Appl. Glycosci., Vol. 48, No. 2, p. 153-161 (2001)]

糖質関連醭素化学シンポジウム

トレハロース生成酵素 MTSase の構造と機能解析

久保田倫夫*，丸田和彦，福田恵温，栗本雅司，辻阪好夫，小林正則1，松浦良樹 ${ }^{1}$

株式会社林原生物化学研究所 天瀬研究所（700-0834 岡山市天瀬南町 7-7）

${ }^{1}$ 大阪大学蛋白質研究所（565-0871 吹田市山田丘 3-2)

Structure and Function Analysis of Malto-oligosyltrehalose Synthase

Michio Kubota, ${ }^{*}$ Kazuhiko Maruta, Shigeharu Fukuda,

Masashi Kurimoto, Yoshio Tsujisaka, Masanori Kobayashi ${ }^{1}$ and Yoshiki Matsuura ${ }^{1}$

Amase Institute, Hayashibara Biochemical Laboratories, Inc.

(7-7, Amase Minami-machi, Okayama 700-0834, Japan)

${ }^{1}$ Protein Institute, Osaka University

(3-2, Yamadagaoka, Suita 565-0871, Japan)

\begin{abstract}
Malto-oligosyltrehalose synthase (EC 5.4.99.15, MTSase) is a glycosyltransferase catalyzing the conversion of maltodextrins to malto-oligosyltrehaloses by forming $\alpha, \alpha-1,1$-glucosidic linkage. The enzyme slightly catalyzes the release of glucose from maltodextrins by hydrolysis of the $\alpha-1,4$ linkage of maltodextrins on the reducing end. The amino acid sequence of MTSase from Sulfolobus acidocaldarius ATCC 33909 showed significant homologies to those of not only other bacterial MTSases but also $\alpha$-amylase family enzymes. The $S$. acidocaldarius MTSase lost the enzyme activity by site-directed mutation of Asp228, Glu255, or Asp443 of the enzyme, which corresponded to the catalytic residues of $\alpha$-amylase family enzymes. The mutation of Lys 390 or Lys 445 brought about a decrease of the transfer activity and an increase of the hydrolysis activity of the enzyme. The two lysine residues are conserved among MTSases but not $\alpha$-amylase family enzymes. The tertialy structure analysis revealed that MTSase as well as $\alpha$-amylase family enzymes contained a $(\beta / \alpha)_{8}$ barrel structure as the catalytic domain. The three carboxyl residues (Asp228, Glu255 and Asp443) proposed as the catalytic center of MTSase were found to be located in the active cleft and positioned similarly to those of $\alpha$-amylase family enzymes. There were two loops and one helix structures on one end of the active cleft, where a nearly closed space was formed. The lysine residues (Lys390 and Lys445) were found to be situated in the closed structure. It was suggested that several residues containing the two lysines in the closed structure were involved in catalysis of the $\alpha, \alpha-1,1$ transfer activity of MTSase.
\end{abstract}

トレハロース ( $\alpha, \alpha$-trehalose) は, 2 分子のグルコー スが $\alpha, \alpha-1,1$ 結合した非還元性の二糖で, 微生物から 動植物まで広く存在している，従来，トレハロース生 合成に関わる酵素系として, トレハロース-6-リン酸 シンターゼ (EC 2.4.1.15) とトレハロースホスファター ゼ（EC 3.1.3.12）によるトレハロース-6-リン酸を経 由する反応が知られていだ．最近になって, 従来の

\footnotetext{
${ }^{*}$ Corresponding author.
}

酵素とは異なったリン酸非依存型の新規トレハロース 生成酵素(系)が 2 種類発見された。一つは，グルコー ス重合度が 3 以上の $\alpha-1,4$ グルカンを基質とする MTSase (Malto-oligosyltrehalose synthase EC 5.4.99.15) $)^{2)}$ と MTHase (Malto-oligosyltrehalose trehalohydrolase, EC 3.4.1.141) ${ }^{3)}$ とからなる酵素系で，もう一 つは，マルトースを直接トレハロースに変換するトレ ハロースシンターゼ (Maltose $\alpha$-D-glucosyltransferase, EC 5.4.99.16) である。これらのうち, MTSase/MTHase 
酵素系は澱粉からトレハロースを高率に生成するた め, トレハロースの工業製造に実用化されている5).

MTSase と MTHase の両酵素は, 土壌から分離され た Arthrobacter sp. Q 36 が生産する菌体内酵素として 初めて見出された ${ }^{6)}$. その後, Arthrobacter ramosus ${ }^{7}$ を 含め多くの Arthrobacter 属細菌が両酵素を生産するこ と ${ }^{8)}$, Sulfolobus 属9.10) など他の細菌種にもその存在 が報告された．いくつかの菌株から遺伝子 DNA がク ローニングされ11-13)，DNA にコードされる酵素蛋白一 次配列が明らかにされているだけでなく，両醳素遺伝 子は一つのオペロンを形成してトレハロース生合成に 働いていると推定されている.

MTSase は $\alpha-1,4$ グルコシド結合の $\alpha, \alpha-1,1$ 結合への 変換を触媒するユニークな転移酵素と考えられてお り，その反応機構については興味深いところが多い. 本稿では，MTSase の転移活性に焦点を当て，酵素構 造と機能との相関について最近の知見をいくつか紹介 する。

\section{MTSase 作用}

MTSase は, アミロースなど $\alpha-1,4$ グルカンの還元 末端グルコースの $\alpha-1,4$ 結合を切断し分子内で $\alpha, \alpha$ 1,1 転移してアミロシルトレハロースを生成する分子 内糖転移を主に触媒する転移酵素である（Fig. 1)。こ の転移反応は可逆的であり，アミロシルトレハロース をアミロースに変換するが, 反応の平衡は $\alpha, \alpha-1,1$ 転 移側 (アミロシルトレハロース生成側)に傾いている. この酵素は分子内転移だけでなく，水分子への転移で
ある水解作用や高濃度グルコース存在下での分子間転 移をわずかに触媒する(14)ことも知られている。グル コース重合度が 3 以上の $\alpha-1,4$ グルカンが基質として 利用されるが，重合度が2のマルトースには作用しな いと考えられている． $\alpha-1,4$ グルカンの還元末端にフ ラクトースが結合した基質の $\alpha 1-\beta 2$ 結合にも作用し 分子内転移や水解を触媒することも報告されてい る $^{15)}$.

このような MTSase の作用について，特徴的な二つ の性質をあげることができる.

1） $\alpha-1,4$ グルカンの還元末端側に exo 型で作用す る.

2）切断した還元末端グルコースの 1 位水酸基 （ $\alpha$-アノマー）に転移する。

この二つの特徵的な作用を，本酵素の構造の観点か ら探索してみようというのが本稿の意図するものであ る.

\section{一次構造解析}

これまで報告されている7種起源の MTSase アミノ 酸一次配列を Fig. 2 に示す. いくつかの㨂入や欠失が 存在するが，いずれも約 700-800 残基から構成されて いる．配列を比較すると，よく保存されている領域が 散在している．保存領域のうち，第 90 残基（S. acidocaldarius MTSase $の$ 残基番号)付近，第 230 残基付近, 第 250-260 残基付近，第 440 残基付近の四つの領域

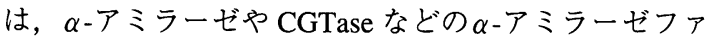
ミリー酵素間で保存されている配列（A-, B-, B'-,

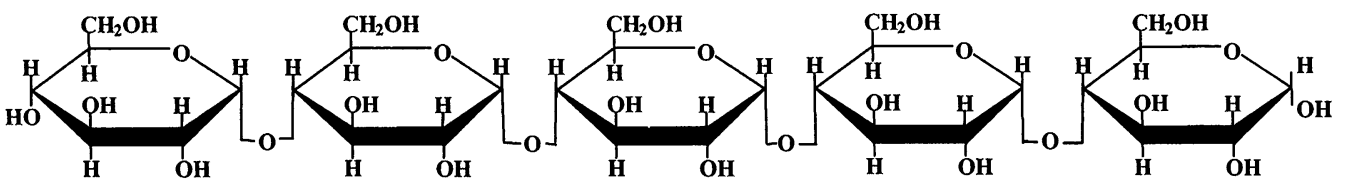

MTSase

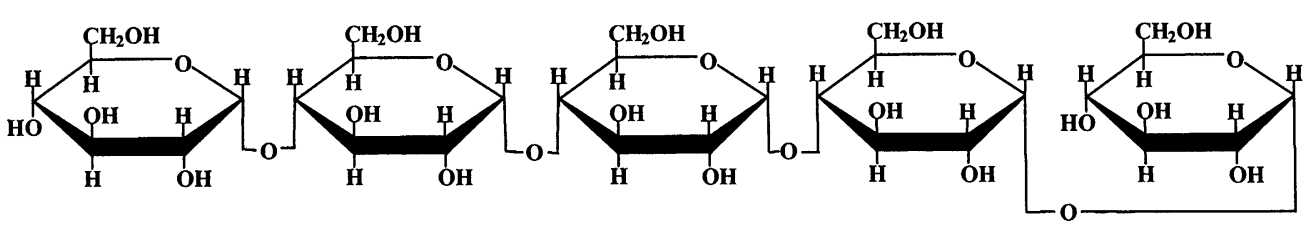

Fig. 1. MTSase reaction. 


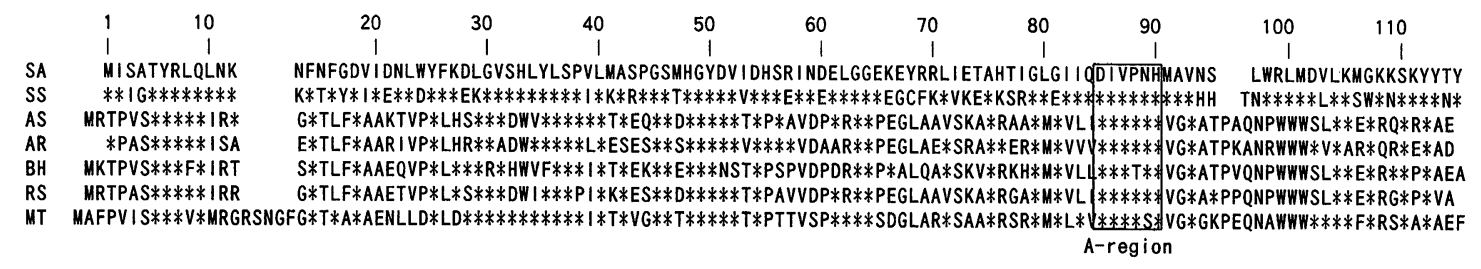

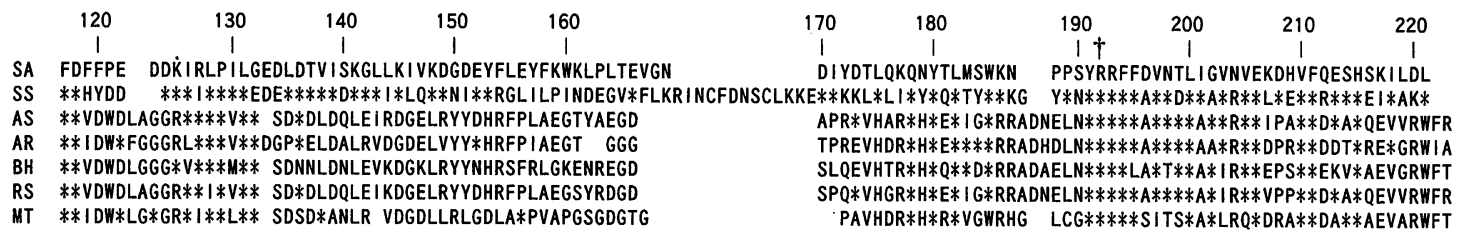

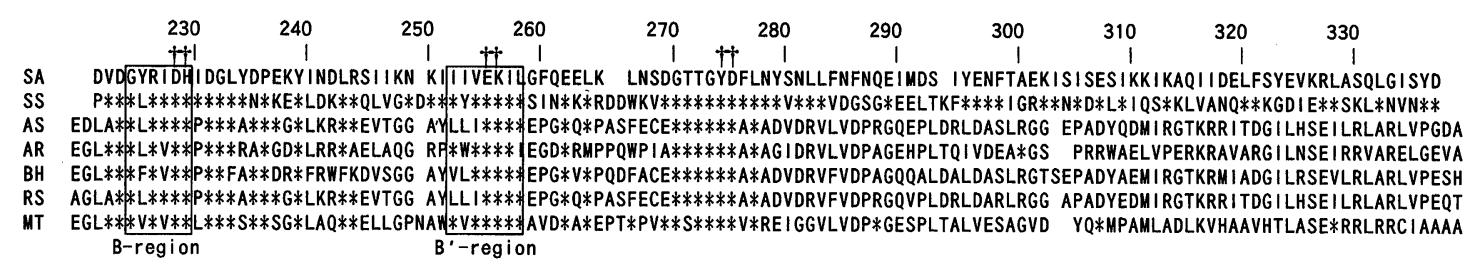

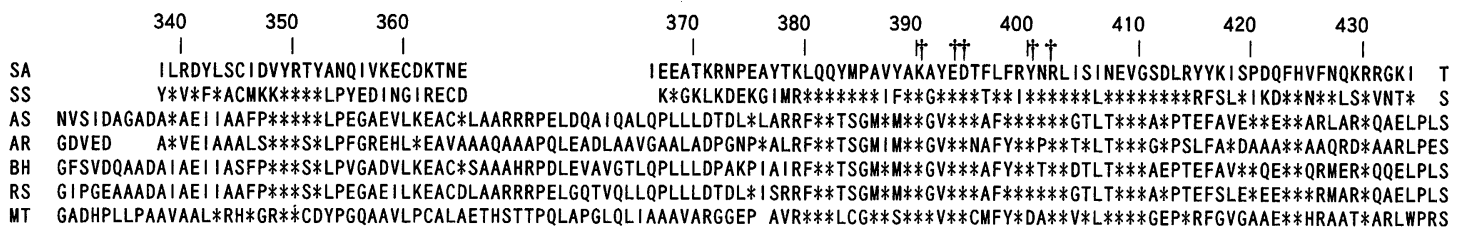

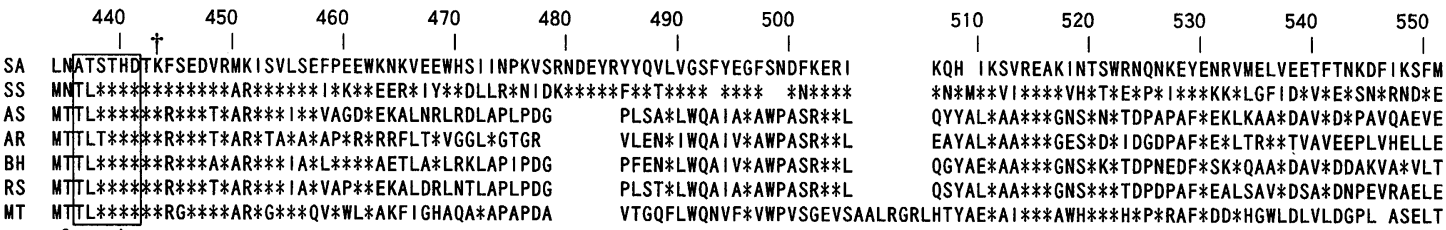
C-region

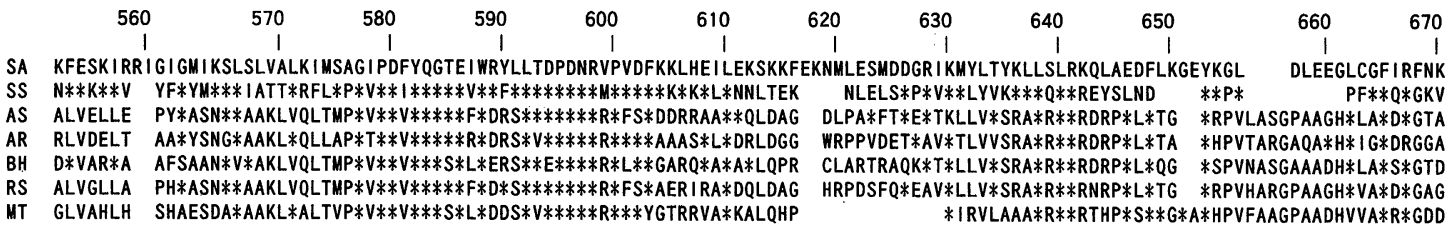

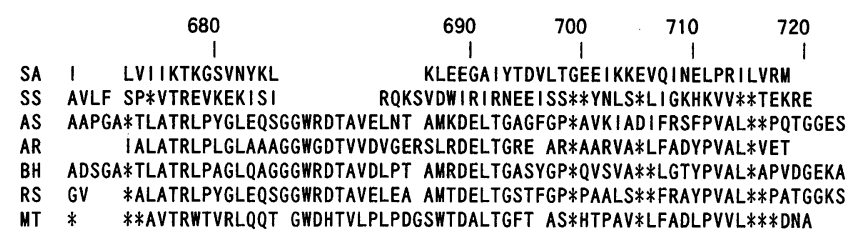

Fig. 2. Amino acid sequence comparison among MTSases from 7 bacterial origins.

SA, from S. acidcaldarius $;{ }^{12)} \mathrm{SS}$, from S. solfataricus ${ }^{26)}$ AS, Arthrobacter sp. ${ }^{11)}$ AR, A. ramousus; BH, Brevibacterium helovolum $;^{27)} \mathrm{RS}$, Rhizobium $\mathrm{sp} .{ }^{13)} \mathrm{MT}$, Mycobacterium tuberculosis. ${ }^{28)}$ The marked ( $\dagger$ ) residues were mutated in this study (see text). The asterisk means the residue identical to that of $S$. acidcaldarius MTSase. 


\begin{tabular}{lcccc}
\hline & \multicolumn{4}{c}{ Conserved Regions } \\
\cline { 2 - 5 } & \multicolumn{1}{c}{ A } & B & B' & C \\
\hline MTSase & DIVPNH & GYRIDH & IIVEKI & ATSTHD \\
$\alpha$-Amylase & DVVYNH & GLRLDA & CIGEAV & FVRNHD \\
G4-Amylase & DVVPNH & GFRFDA & CVGELW & FVDNHD \\
CGTase & DFAPNH & GIRFDA & TFGEWF & FIDNHD \\
Maltase & DLVINH & GFRIDT & RVGEVA & YIENHD \\
Pullulanase & DVVYNH & GFRFDL & FFGEGW & YVSKHD \\
Isoamylase & DVVYNH & GFRFDL & LFAEPW & FIDVHD \\
Branching enzyme & DWVPGH & GFRVDA & MIAEDS & LPFSHD \\
& & & & \\
\hline
\end{tabular}

Fig. 3. The conserved regions among MTSase and the $\alpha$-amylase family enzyme.

MTSase from $S$. acidcaldarius $;{ }^{12)} \alpha$-amylase from Aspergillus oryzae ${ }^{29)}$ G4-Amylase from Pseudomonas stutzeri $;^{30)}$ CGTase from Bacillus stearothermophilus $;{ }^{31)}$ maltase from Saccharomyces carlsbergensis $;{ }^{32)}$ pullulanase from Klebsiella aerogenes $;{ }^{33)}$ isoamylase from Flavobacterium sp. ${ }^{34)}$ branching enzyme from B. stearothermophilus. ${ }^{35)}$

C-region) ${ }^{16)}$ と類似していた（Fig. 3)。また，第 50 残 基付近の HGYD や第 600 残基付近の DPDNR の配列 も $\alpha$-アミラーゼや CGTase によく保存されているもの であった。これらの領域のアミノ酸残基は, 既に立体 構造が決定されている $\alpha$-アミラーゼファミリー酵素 では活性クレフトを構成していることがわかってい る $^{17-20)}$. これらの一次配列の情報は, MTSase が $\alpha$-ア ミラーゼファミリー酵素と類似した活性クレフトを有 し, MTSase 転移機構の一部分は $\alpha$-アミラーゼ作用と 共通していることを示唆するものであった.

\section{部位特異的変異}

部位特異的変異解析は, 酵素蛋白の構造と機能との 相関を研究する上において有力な手法である．著者ら は，S. acidocaldarius の MTSase 遺伝子を用いて部位 特異的変異解析を行った ${ }^{21}$. S. acidocaldarius の遺伝

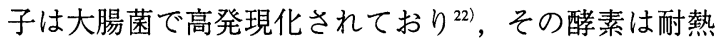
性が高い $\left(85^{\circ} \mathrm{C}\right)$ ため，組換え酵素の調製や取扱いが 容易であった．また，遺伝子 DNAへの変異も市販の キット（Takara 社製）を用いて高頻度で得ることが できた。

\section{1. 触媒残基}

$\alpha$-アミラーゼファミリー酵素の触媒残基は，保存 領域 $\mathrm{B}, \mathrm{B}{ }^{\prime}, \mathrm{C}$ の中の三つの酸性残基であると提唱さ れている ${ }^{23)}$. MTSase 配列中にも，これら酸性残基 （Asp228，Glu255，Asp443）は保存されており, 本酵 素においても触媒基として働いている可能性が考えら
れた.そこで,それぞれの残基の変異体 Asp228Asn, Glu255Gln，Asp443Asn を作製し，組換え大腸菌の高 発現系で蛋白生産させ，ゲル電気泳動法（native PAGE, SDS-PAGE）で抽出液中の変異酵素蛋白の存 在を確認した後, 抽出液中の酵素活性を測定したとこ ろ，いずれの変異体においても本酵素活性は検出され なかった。この結果は, Asp228, Glu255, Asp443が MTSase の触媒残基であることを強く支持するもので あり， $\alpha$-アミラーゼの触媒残基と類似した働き（お そらく, $\alpha-1,4$ 結合の切断と水酸基への転移）に関与 している可能性を示唆した.

\section{2. 転移に関与する残基}

MTSase の配列には， $\alpha$-アミラーゼファミリー酵素 と類似したもの以外に, MTSase 間のみで保存されて いる配列が存在する。そのような配列の中には MTSase の特異的な $\alpha, \alpha-1,1$ 転移に関与する残基が含 まれている可能性があると考え，Table 1 に示す 12 個 のアミノ酸残基について部位特異的変異解析を行っ た．遺伝子 DNA に変異を導入した後，大腸菌の中で 高発現化して変異酵素蛋白を生産させた，変異酵素を 含む抽出液を熱処理 $\left(60^{\circ} \mathrm{C}\right)$ して宿主大腸菌の挟雑活 性を失活させた後，基質マルトペンタオースを用いて 転移活性（還元力の低下） と水解活性（グルコースの 遊離）を測定した。その結果，1）Arg192，Asp275, Tyr400, Arg402 の変異は両活性への影響は少ない, 2）Asp231，Lys256，Tyr274 の変異は両活性を大幅に 減少させる，3）His229，Glu393 の変異は両活性を消 
Table 1. Transglycosylation and hydrolysis activities of the mutated MTSases.

\begin{tabular}{lcc}
\hline Mutation & $\begin{array}{c}\text { Transglycosylation }^{a} \\
(\%)\end{array}$ & $\begin{array}{c}\text { Hydrolysis }^{a} \\
(\%)\end{array}$ \\
\hline Arg192Ala & 40.1 & 1.1 \\
His229Asn & $<0.4$ & $<0.04$ \\
Asp231Ala & 7.9 & 0.51 \\
Lys256Thr & 3.5 & 0.39 \\
Tyr274Ser & 2.6 & 0.27 \\
Asp275Ala & 43.2 & 1.0 \\
Lys390Thr & 16.0 & 4.7 \\
Glu393Ala & $<0.4$ & $<0.04$ \\
Asp394Ala & 1.7 & 1.1 \\
Tyr400Ser & 80.8 & 1.5 \\
Arg402Ser & 71.2 & 1.3 \\
Lys445Thr & 3.9 & 2.7 \\
Wild-type & 100 & 2.0 \\
\hline
\end{tabular}

${ }^{a}$ Maltopentaose $(1 \%)$ was incubated with the enzyme at $60^{\circ} \mathrm{C}, \mathrm{pH} 6.0$ for $1 \mathrm{~h}$. The decrease of the reducing power was measured by the Somogyi-Nelson method for the transglycosylation activity. The release of glucose was assayed by the glucose oxdase method for the hydrolysis activity.

失させる，4）Lys390, Asp394, Lys445 の変異は転移 活性を減少させるが，水解活性の減少は少ない，もし くは逆に増加させることがわかった。

Lys390，Lys445を種々のアミノ酸に置換したとこ ろ, Table 2 に示すように，両Lys とも大きな側鎖を 有する Trpへの置換によって転移活性のみが大幅に減
少し，見かけの転移活性は消失した。また，Lys390 Arg, Lys445His, Lys445Arg の類似残基への变異で は, 転移に対する水解の比率は減少する（転移性が相 対的に回復する）こともわかった，見かけの転移活性 が消失した Trpへの変異酵素について, 転移と水解に よる生成物を HPLCで定量したところ（Table 3），グ ルコース，マルトテトラオースなど水解物の生成量 は， $\alpha, \alpha-1,1$ 転移生成物のマルトトリオシルトレハ ロース量より多く，水解活性が優勢になっていること が確認された。特に, Lys390Trp 変異酵素の水解活性 は転移活性の約 2 倍であった。水解活性の $K_{\mathrm{m}}$ 值を測 定したところ, $17.8 \mathrm{mM}$ (Lys390Trp), $16.2 \mathrm{mM}$ (Lys 445Trp）と wild-type 酵素 (5.2 mM) の約 3 倍の值で あり，それぞれ置換によって基質結合の親和性は低下 していた。

以上の部位特異的変異解析の結果, 構造と機能との 相関に関して重要な二つの知見が得られたと考えてい る。一つは，先に述べた $\alpha$-アミラーゼファミリー醰 素と共通する触媒残基 Asp228, Glu255, Asp443 に加 えて，MTSase に特有な残基である His229, Glu393 も 本酵素活性に必須であることと，もう一つは，Lys 390，Asp394，Lys445 が本酵素の転移活性に関与して いる可能性が示唆されたことである.

\section{立体 構 造}

S. acidocaldarius の MTSase 蛋白をリジン還元メチ ル化した後, 結晶化を行った ${ }^{24)}$. 得られた結晶を $X$ 線

Table 2. Transglycosylation and hydrolysis activities of the mutations substituted for Lys390 and Lys445.

\begin{tabular}{lccc}
\hline Mutation & $\begin{array}{c}\text { Transglycosylation }(A) \\
(\%)\end{array}$ & $\begin{array}{c}\text { Hydrolysis }(B) \\
(\%)\end{array}$ & $\begin{array}{c}(B) /(A) \\
(\%)\end{array}$ \\
\hline Lys390His & 24.2 & 6.3 & 26.0 \\
Lys390Gln & 17.8 & 4.9 & 27.5 \\
Lys390Arg & 19.1 & 0.58 & 3.0 \\
Lys390Trp & $<0.7$ & 3.3 & $>470$ \\
Lys390Ala & 11.5 & 7.7 & 67.0 \\
Lys390Glu & 21.0 & 7.5 & 35.7 \\
Lys390Thr & 22.9 & 7.2 & 31.4 \\
Lys445His & 14.3 & 2.1 & 14.7 \\
Lys445Gln & 7.2 & 4.3 & 59.7 \\
Lys445Arg & 23.0 & 4.3 & 18.7 \\
Lys445Trp & $<0.7$ & 2.5 & $>350$ \\
Lys445Ala & 7.9 & 4.4 & 55.7 \\
Lys445Glu & 7.1 & 3.9 & 54.9 \\
Lys445Thr & 6.9 & 4.0 & 58.0 \\
Wild-type & 100 & 1.4 & 1.4 \\
\hline
\end{tabular}


Table 3. Reaction products from maltopentaose by the Lys390Trp and Lys445Trp mutated MTSase.

\begin{tabular}{lclcc}
\hline \multirow{2}{*}{ Enzyme } & \multicolumn{4}{c}{ Products (mol\%) } \\
\cline { 2 - 5 } & G 1 & G 2 & G 4 & G 3-Tre \\
\hline Lys390Trp & 40.9 & 1.6 & 38.0 & 19.5 \\
Lys445Trp & 35.5 & 1.4 & 33.4 & 30.3 \\
Wild-type & 1.0 & 0 & 0.3 & 98.7 \\
\hline
\end{tabular}

G 1, G 3, G 4, and G 3-Tre mean glucose, maltotriose, maltotetraose and maltotriosyltrehalose, respectively.

結晶構造解析を行い, 1.9 A分解能で立体構造を決定し た。

MTSase の構造は，既に立体構造が決定されている $\alpha$-アミラーゼファミリー酵素と基本的に類似してお り， $\beta / \alpha$ バレルを骨格とした構造であった。バレルの $\mathrm{C}$ 末端側にはクレフトが形成しており, クレフト構造

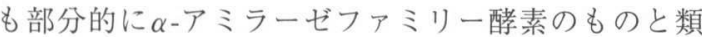
似しており，このクレフトが MTSase の活性部位と考 えられた. MTSaseの立体構造の詳細については, 別 に報告することを予定しており，本稿では活性部位の 一部分のみを概説する.

MTSase の活性部位を Fig. 4に示す。活性部位の中 心には，触媒残基として推定したAsp228，Glu255， Asp443 が， $\alpha$-アミラーゼの触媒残基とほほ同じ位置 に存在した。近辺には His90, Arg226, His442など $\alpha$ アミラーゼファミリー酵素で保存されている残基があ り，それらは基質結合に関与していると考えられ，触 媒残基とともにサブサイト-1 を構成していると思わ

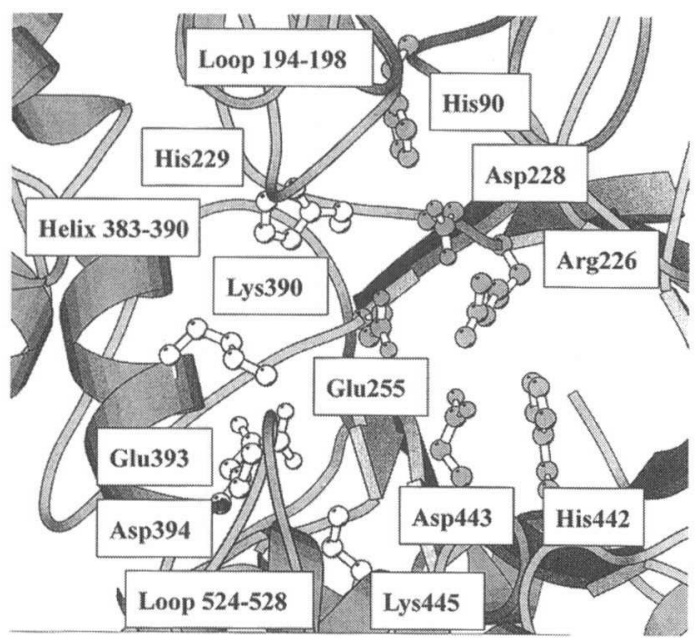

Fig. 4. The active site structure of MTSase.
れた。クレフトの一端（Fig. 4の中央から左側）には, 二つのループ (Loop 194-198, Loop 524-528) と一つ のヘリックス（Helix 383-390）に囲まれた構造が存在 しており, 触媒基との位置関係からサブサイト +1 と 推定された。サブサイト+1には, 部位特異的変異解 析で指摘された His229, Lys390, Glu393, Asp394, Lys445 が存在した。興味あることに，転移に関与す ると示唆されたLys390，Asp394，Lys445 はお互いに 水素結合可能な構造であった。また，部位特異的変異 によって大幅に活性減少をもたらしたAsp231, Lys 256, Tyr274 はいずれもサブサイト +1 周辺に存在し, その構造を維持しているように思われた。

現在，著者らは Fig. 5に示すような MTSase 反応機 構を考えている。

（1）まず，基質（ $\alpha-1,4$ グルカン）が MTSase の活 性クレフトに結合する．グルカンの還元末端グルコー スは MTSaseの二つのループと一つのヘリックスに囲 まれたサブサイト +1 に結合する（おそらく， $\alpha$-ア）

(1)

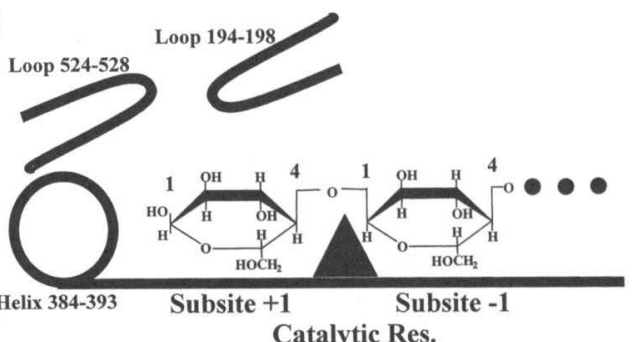

1

(2)

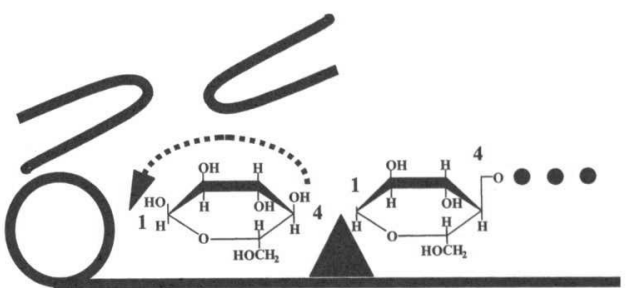

(3)

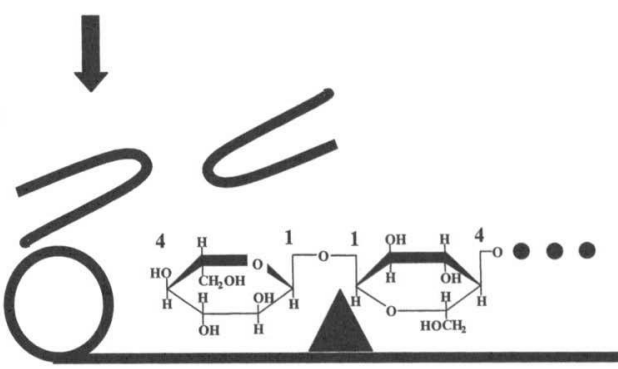

Fig. 5. A possible mechanism for the $\alpha, \alpha-1,1$ transglycosylation of MTSase. 
マーの基質のみがプロダクティブな結合を形成すると 考えられる). その隣の $\alpha-1,4$ 結合は触媒基 (Asp228, Glu255, Asp443）を跨ぎ, 非還元側のグルカン鎖は $\alpha$-アミラーゼと類似した構造のサブサイト-1 などと 結合する。

（2）還元末端側の $\alpha-1,4$ 結合は，触媒基によって切

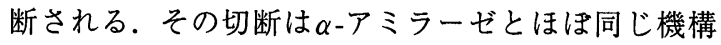
と考えられ, 切断された結合の 1 位は触媒基などと相 互作用して触媒中心に保持されている。切断された還 元末端グルコースは, ループ構造の存在のためにサブ サイト+1 から遊離することができず, サブサイト中 で約 $180^{\circ}$ 反転し，その 1 位水酸基（ $\alpha$-アノマー）が 触媒中心に接近するように位置する。

（3）触媒中心に保持されていたグルカン鎖の 1 位 は, その $\alpha$-アノマーの方向からグルコースの 1 位水 酸基（ $\alpha$-アノマー）に転移する. その結果, $\alpha, \alpha-1,1$ 結合が形成する。

この反応モデルは, 先に提起した MTSase の特徵的 な二つの性質, $\alpha-1,4$ グルカンの還元末端側に exo 型 で作用することと, 切断した還元末端グルコースの 1 位水酸基（ $\alpha$-アノマー）に転移することを合理的に 説明することができる．また，Fig. 4からもわかるよ うに, 二つのループはサブサイト+1を完全にふさい でいる構造ではなく, ループ構造の摇らぎなどを考慮 すると, サブサイト+1 からのグルコースの遊離また は進入は可能と考えられ，そのことは MTSase が示す わずかなグルコース遊離活性や分子間転移活性をうま く説明することができる. しかしながら, 反応の詳細 な部分についてはこのモデルだけでは解釈ができない 問題点も残されている. 例えば, MTSaseの転移反応 は可逆的であり, サブサイト+1のグルコースの 1 位 水酸基（ $\alpha$-アノマー）だけでなく，4 位水酸基にも転 移可能である. しかし， 1 位水酸基（ $\alpha$-アノマー）は axial で, 4 位水酸基は equatorial とそれぞれ異なる方

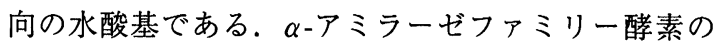
CGTase の場合, 1 位水酸基は equatorial の $\beta$-アノマー のみ利用されネオトレハロースが生成する25)。なぜ, MTSase は axial の $\alpha-ア ノ マ ー 1$ 位水酸基に転移でき るのであろうか？ また，なぜ，グルコースの 1 位や 4 位以外の水酸基に転移しないのであろうか? この ような問題点を解決するためには，より詳細に構造解 析，特に，基質（アナログ） MTSase 複合体の立体構 造解析が必要と考えている.

以上のように, 著者らは MTSase の部位特異的変異 解析と立体構造解析を行い, MTSase が $\alpha$-アミラーゼ
ファミリー酵素と類似した酵素蛋白であることと， MTSase に特有と考えられる構造とを見出した. 構造 と機能との相関研究をさらに推し進め, MTSase 分子 内転移反応機構の解明の一助としたい.

\section{文献}

1 ) A.D. Elbein: The metabolism of $\alpha, \alpha$-trehalose. $A d v$. Carbohydr. Chem. Biochem., 30, 227-256 (1974).

2 ) T. Nakada, K. Maruta, K. Tsusaki, M. Kubota, H. Chaen, T. Sugimoto, M. Kurimoto and Y. Tsujisaka: Purification and properties of a novel enzyme, maltooligosyl trehalose synthase, from Arthrobacter sp. Q 36. Biosci. Biotechnol. Biochem., 59, 2210-2214 (1995).

3 ) T. Nakada, K. Maruta, H. Mitsuzumi, M. Kubota, H. Chaen, T. Sugimoto, M. Kurimoto and Y. Tsujisaka: Purification and characterization of a novel enzyme, maltooligosyl trehalose trehalohydrolases, from $\mathrm{Ar}$ throbacter sp. Q 36. Biosci. Biotechnol. Biochem., 59, 2215-2218 (1995).

4 ) T. Nishimoto, T. Nakada, H. Chaen, S. Fukuda, T. Sugimoto, M. Kurimoto and Y. Tsujisaka: Purification and characterization of a thermostable trehalose synthase from Thermus aquaticus. Biosci. Biotechnol. Biochem., 60, 835-839 (1996).

5 ) 杉本利行, 久保田倫夫, 仲田哲也, 津崎桂二：新 規酵素による澱粉からのトレハロース製造。農 化, 72, 915-922 (1998).

6 ) K. Maruta, T. Nakada, M. Kubota. H. Chaen, T. Sugimoto, M. Kurimoto and Y. Tsujisaka: Formation of trehalose from maltooligosaccharides by a novel enzymatic system. Biosci. Biotechnol. Biochem., 59, 1829-1834 (1995).

7 ) 渡辺 光, 山本拓生, 丸田和彦, 久保田倫夫, 福 田恵温, 栗本雅司, 辻阪好夫：Arthrobacter ramosus S 34 由来のトレハロース生成酵素. 農化（講 演要旨), 73, 39 (1999).

8 ) 丸田和彦, 山下 洋, 久保田倫夫, 福田恵温, 栗 本雅司：Arthrobacter 属細菌におけるトレハロー ス (tre) オペロン. 農化 (講演要旨), 72, 320 (1998).

9 ) T. Nakada, S. Ikegami, H. Chaen, M. Kubota, S. Fukuda, T. Sugimoto, M. Kurimoto and Y. Tsujisaka: Purification and characterization of thermostable maltooligosyl trehalose synthase from the thermoacidophile archaebacterium Sulfolobus acidocaldarius. Biosci. Biotechnol. Biochem., 60, 263-266 (1996).

10) T. Nakada, S. Ikegami, H. Chaen, M. Kubota, S. Fukuda, T. Sugimoto, M. Kurimoto and Y. Tsujisaka: Purification and characterization of thermostable maltooligosyl trehalose treharohydrolase from the thermoacidophile archaebacterium Sulfolobus acido- 
caldarius. Biosci. Biotechnol. Biochem., 60, 267-260 (1996).

11) K. Maruta, K. Hattori, T. Nakada, M. Kubota, T. Sugimoto and M. Kurimoto: Cloning and sequencing of trehalose biosynthesis genes from Arthrobacter sp. Q 36. Biochim. Biophys. Acta, 1289, 10-13 (1996).

12) K. Maruta, H. Mitsuzumi, T. Nakada, M. Kubota, H. Chaen, S. Fukuda, T. Sugimoto and M. Kurimoto: Cloning and sequencing of a cluster of genes encoding novel enzymes of trehalose biosynthesis from thermophilic archaebacterium Sulfolobus acidocaldarius. Biochim. Biophys. Acta, 1291, 177-181 (1996).

13) K. Maruta, K. Hattori, T. Nakada, M. Kubota, T. Sugimoto and M. Kurimoto: Cloning and sequencing of trehalose biosynthesis genes from Rhizobium sp. M-11. Biosci. Biotechnol. Biochem., 60, 717-720 (1996).

14) M. Kato, K. Takehara, M. Kettoku, K. Kobayashi and T. Shimizu: Subsite structure and catalytic mechanism of a new glycosyltrehalose-producing enzyme isolated from the hyperthermophilic archaeum Sulfolobus solfataricus KM 1. Biosci. Biotechnol. Biochem., 64, 319-326 (2000).

15) 阿賀 創, 渋谷 孝, 杉本利行, 福田恵温, 栗本 雅司, 辻阪好夫：Arthrobacter sp. Q 36 由来, マ ルトオリゴシルトレハロース生成酵素のマルトテ トラオシルスクロースへの作用. 農化（講演要 旨)，70，296 (1996).

16) A. Nakamura and K. Yamane: The primary structure of several amylolytic enzymes. in Enzyme Chemistry and Molecular Biology of Amylases and Related Enzymes, The Amylase Research Society of Japan, eds., CRC Press, Tokyo, pp. 83-87 (1994).

17) Y. Matsuura, M. Kusunoki, W. Harada and M. Kakudo: Structure and possible catalytic residues of Taka-amylase A. J. Biochem., 95, 697-702 (1984).

18) Y. Morishita, K. Hasegawa, Y. Matsuura, Y. Katsube, M. Kubota and S. Sakai: Crystal structure of a maltotetraose-forming exo-amylase from Pseudomonas stutzeri. J. Mol. Biol., 267, 661-672 (1997).

19) 久保田倫夫, 松浦良樹, 堺 修造, 勝部幸輝: : クロデキストリン合成酵素の立体構造と機能発 現. 応用糖質科学, 41, 245-253 (1994).

20) Y. Katsuya, Y. Mezaki, M. Kubota and Y. Matsuura: Three-dimensional structure of Pseudomonas isoamylase at 2.2 A resolusion. J. Mol. Biol., 281, 885-897 (1998).

21) 丸田和彦, 山下 洋, 久保田倫夫, 福田恵温, 栗 本雅司: MTSase の部位特異的変異解析. 農化 (講演要旨)，71，153 (1997).

22) 丸田和彦，三鼓仁志，仲田哲也，池上庄司，久保 田倫夫, 茶圓博人, 福田恵温, 栗本雅司: Sulfolobus acidocaldarius 由来のトレハロース生成遺 伝子の大腸菌での高発現化. 農化 (講演要旨), 70, 294 (1996).

23) K. Hasegawa, M. Kubota and Y. Matsuura: Roles of catalytic residues in $\alpha$-amylases as evidenced by the structures of the product-complexed mutants of a maltotetraose-forming amylase. Protein Eng., 12, 819-824 (1999).

24) M. Kobayashi, M. Kubota and Y. Matsuura: Crystallization and improvement of crystal quality for $\mathrm{x}$-ray diffraction of maltooligosyl trehalose synthase by reductive methylation of lysine residues. Acta Crystallogr., 55, 931-933 (1999).

25) S. Kobayashi: Cyclodextrin producing enzyme (CGTase). Prog. Biotechnol., 12, 23-41 (1996).

26) K. Kobayashi, M. Kato, Y. Miura, M. Kettoku, T. Komeda and A. Iwamatsu: Gene cloning and expression of new trehalose-producing enzymes from the hyperthermophilic archaeum Sulfolobus solfataricus KM 1. Biosci. Biotechnol. Biochem., 60, 1882-1885 (1996).

27) Y.H. Kim, T.K. Kwon, S. Park, H.S. Seo, J.J. Cheong, C.H. Kim, J.K. Kim, J.S. Lee and Y.D. Choi: Trehalose synthesis by sequential reactions of recombinant maltooligosyltrehalose synthase and maltooligosyltrehalose trehalohydrolase from Brevibacterium helvolun. Appl. Environ. Microbiol., 66, 4620-4624 (2000).

28) S.T. Cole, R. Brosch, J. Parkhill, T. Garnier, C. Churcher, D. Harris, S.V. Gordon, K. Eiglmeier, S. Gas, C.E. Barry, III, F. Tekaia, K. Badcock, D. Basham, D. Brown, T. Chillingworth, R. Connor, R. Davies, K. Devlin, T. Feltwell, S. Gentles, N. Hamlin, S. Holroyd, T. Hornsby, K. Jagels, A. Krogh, J. McLean, S. Moule, L. Murphy, S. Oliver, J. Osborne, M.A. Quail, M.A. Rajandream, J. Rogers, S. Rutter, K. Seeger, S. Skelton, S. Squares, R. Squares, J.E. Sulston, K. Taylor, S. Whitehead and B.G. Barrell: Deciphering the biology of Mycobacterium tuberculosis from the complete genome sequence. $\mathrm{Na}$ ture, 393, 537-544 (1998).

29) H. Toda, K. Kondo and K. Narita: The complete amino acid sequence of Taka-amylase A. Proc. Jpn. Acad., 58, 208-212 (1982).

30) M. Fujita, K. Torigoe, T. Nakada, K. Tsusaki, M. Kubota, S. Sakai and Y. Tsujisaka: Cloning and nucleotide sequence of the gene $(a m y P)$ for maltotetraose-forming amylase from Pseudomonas stutzeri MO-19. J. Bacteriol., 171, 1333-1339 (1989).

31）堺 修造，久保田倫夫，山本康三，仲田哲也，鳥 越角二, 安藤 理, 杉本利行: B. stearothermophilus と B. macerans の CGTase 遺伝子のクロー ニングと構造解析. 澱粉科学, 34, 140-147 (1987).

32) S.H. Hong and J. Marmur: Primary structure of the maltase gene of the MAL 6 locus of Saccharomyces carlsbergesis. Gene, 41, 75-84 (1986).

33) N. Katsuragi, N. Takizawa and Y. Murooka: Entire nucleotide sequence of the pullulanase gene of Klebsiella aerogenes W 70. J. Bacteriol., 169, 2301- 
2306 (1987).

34) B.M. Krohn, G.F. Barry and G.M. Kishore: An isoamylase with neutral $\mathrm{pH}$ optimum from a Flavobacterium species: Cloning, characterization and expression of the iam gene. Mol. Gen. Genet., 254, 469478 (1997).

35) J.A.K.W. Kiel, J.M. Boels, G. Beldman and G. Venema: Molecular cloning and nucleotide sequence of the glycogen branching enzyme gene $(g \lg B)$ from Bacillus stearothermophilus and expression in Escherichia coli and Bacillus subtilis. Mol. Gen. Gen., 230, 136-144 (1991).

\section{【質 問】}

鹿児島大 菅沼

1) $\alpha, \alpha-1,1$ と $\alpha-1,4$ 結合でエネルギー的に余り差 がないとすれば, 還元末端由来のグルコースがサブサ イト+1に閉じ込められて「濃縮」して存在すると考 えれば，あとは単純な平行論で $\alpha, \alpha-1,1$ 結合形成が説 明できるのではないでしょうか?

2） $\alpha$-アノマーの基質分子だけが酵素と結合する とすれば，末端グルコース分子のムタロテーションは 必要ないでしょうか?

\section{【答】}

1) MTSase の $\alpha, \alpha-1,1$ 結合形成能の概容はその通 りと推定しております. MTSase によるフラクトース の水酸基への転移（グルコースの場合と比べると微弱 であるが）は非特異的であることがわかっています。 それに対して，グルコースには 1 位（または 4 位）の 水酸基（ $\alpha$-アノマー）に特異的に転移します。この 特異性が MTSase の反応機構の問題点と考えておりま す.

2 ）指摘のように，おそらく， $\alpha$-アノマーの基質 のみがプロダクティブな結合可能と想像しておりま す.

\section{【質 問】} 江崎グリコ 栗木

MTSaes の $\alpha, \alpha-1,1$ 結合の形成は, いったん反応中 間体ができた状態で，グルコースの C-1 に結合してい る $\mathrm{OH}$ のプロトンが, 反応の第 1 段階でプロトンド ナーとして働きプロトンを解離した状態にある Gluに よって引き抜かれて， $\alpha$-アノマー側から攻撃すると 考えられませんか？たまたま，もともとの分子内の グルコースが何らかの機構で比較的導入され易い状態
になっていると考えられないでしょうか.例えば, $\alpha$ 1,4 結合を $\alpha-1,6$ 結合につなぎ換えるブランチングエ ンザイムと同じ機構で説明できるとおもいますが.

【答】

詳しい機構はまだよく説明できませんが，おそら

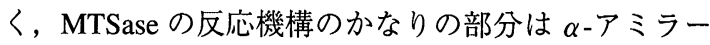
ゼファミリー酵素と共通していると考えております. 指摘の通りかもしれません。しかし，アクセプターグ ルコースの水酸基と酵素触媒基，さらにドナーグルカ ンの C-1 炭素との関係は, それらの構造や状態を含 め, MTSase 反応にとって根本的に重要な問題点であ り，今後の課題と認識しております.

\section{【質 問】}

京府大 大西

G 2 は結合するのか. 基質にならないというが，観 測しきれていないのではないか. 分子内転移なら G 2 は基質になるはずであると思うが?

\section{【答】}

通常の反応条件では，G2（マルトース，トレハロー ス）は基質とならない.しかし，指摘のように，観測 しきれていない可能性は否定できない，例えば，高濃 度マルトース中で, 長時間, 多量の酵素を作用させる 条件で反応するかどうか，現在，不明です.

【質 問】

花王 袴田

1) リジン変異酵素の酵素的性質の変化は？（pH， 温度, 比活性)

2 ) 活性クレフトのループの変異は?デレーション 変異を含めて.

\section{【答】}

1)まだ，精製酵素での検討は行っておりません. おそらく，転移の比活性は $1 / 10$ 程度低下しており， 水解の比活性は数倍に上昇していると考えておりま す.

2 ) ループを対象とした変異はまだ行っておりませ ん. 重要な実験なので, 是非, 調べてみようと考えて おります。

(2000 年 11 月 28 日受付) 